\title{
PHENOMENON OF TAX LOSSES OF STATE BUDGETARY RESOURCES
}

\author{
Larysa SIDELNYKOVA', \\ Kherson National Technical University, Ukraine
}

\begin{abstract}
The aim of this work is structuring categorical-conceptual apparatus of the of the tax losses phenomenon in the state budgetary resources, namely clarification of the concepts of "tax gap", "tax expenditures", "tax losses", as well as the quantification of tax losses of the Consolidated budget of Ukraine. Methodology. Most modern scholars interpret the tax gaps as the amount of taxes that were not received with the budget as a result of shadow economy, tax evasion and the existence of tax debt. However, considerable asymmetry of the tax component of the state budgetary resources also arises due to budget losses of all levels as a result of providing tax exemptions. In modern economic literature such losses are considered as tax expenditures. We consider tax losses a generalizing concept including potential amounts of tax revenues that the state and local budgets have not received as a result of the existence of the phenomenon of "tax gaps" and "tax expenditures", and the amount of losses of the state budgetary resources in terms of their tax component is equal to the sum total of tax exemptions provided, unsettled tax debt of economic agents and the loss of tax revenue due to the operation of shadow economy. The study is based on the analysis of tax losses of budgetary resources of Ukraine during the period of time from 2004 to 2014. The results of the study showed enormous losses of budgetary resources in Ukraine due to the imperfection of the tax system, spread of undisclosed operations, tax evasion, and inefficient fiscal policy implementation. The Consolidated budget loses the amounts of monetary funds, equal to an average of $53.30 \%$ of actual revenue over the period studied. Total tax losses of the state budgetary resources in 2014 are equivalent to the total actual expenditures of the Consolidated budget of Ukraine on social protection and social security, defense, public order, security and judicial authorities. Even taking into account the point of view of foreign economists that only $1 / 3$ of the tax gap can be converted into actual tax revenues in case of implementing measures of legalization of the economy, additional budgetary resources of the Consolidated budget of Ukraine obtained due to the elimination of tax gaps would be significant. It was determined that the effective management of tax gaps and tax expenditures and, consequently, a decrease in tax losses of budgetary resources will ensure the correction of fiscal asymmetries and imbalances, will contribute to achieving fiscal equilibrium, will cause a synchronization of fiscal and monetary policy, and as a result, will reduce the need of Ukraine in loan financing and its debt bondage. Practical implications. Justification of the conclusion that the major reserves to increase the tax component of budgetary resources of the state with preventing tax losses lie exactly in the plane of fiscal policy optimization and legalization of assets of business entities, allows to develop areas of improvement tax forms of financing public spending. Value/originality. The data obtained are able to provide a better understanding of the causes of public finances imbalances in Ukraine and ways of their stabilization.
\end{abstract}

Key words: tax gaps, tax expenditures, tax losses, state budgetary resources, shadow economy, tax debt, tax exemptions.

JEL Classification: $\mathrm{H} 26, \mathrm{H} 30, \mathrm{H} 69$

\section{Introduction}

At the present stage of development of society taxation is a factor determining economic policies of the state as a whole, as well as of separate administrative-territorial units and citizens in particular. Taxation is a significant component of the budgetary resources of the state and a powerful regulator of social and economic processes in the society. At the same time, the most challenging issue in Ukraine nowadays is a problem of tax losses growth in budgets of all levels, closely linked to the issues of ensuring the effective implementation of state fiscal policy and directly affecting its institutions. Therefore, in the context of creating the conditions for sustainable development of Ukraine the most important role is played with the research of theoretical bases of forming institutional environment countering tax losses and with the development of practical recommendations on how to

Corresponding author:

${ }^{1}$ Department of Fiscal and Budgetary Policy, Kherson National Technical University.

E-mail: 1907@i.ua 
reduce the amounts of tax revenue short received with the state due to the inefficiency of fiscal policy implementation and violations of tax laws with economic entities. Thus, there is a clear need of improving fiscal policy of Ukraine requiring the elaboration of theoretically and practically balanced tax losses minimizing system, which would be able to provide resources accumulation of budgets of all levels recognizing the realities of modern life and not contradicting to the criteria of fiscal sufficiency.

\section{Theoretical bases of $\operatorname{tax}$ losses of budgetary resources}

The research of multifactor decomposition of tax losses of budgetary resources of the state should start with structuring categorical-conceptual apparatus of this phenomenon, namely with the clarification of the concepts of "tax gap", "tax expenditures", "tax losses".

According to international standards, the tax gap is the difference between the amount of tax payments, which is to be received with the budget if all taxpayers declare their income and pay taxes voluntarily, correctly, timely and fully on the one hand and the amount of taxes actually paid - on the other [Monitoring Taxpayers' Compliance, 2008].

This definition is widely used by foreign scientists and experts. Thus, the American economist E. Toder considers the tax gap as the difference between the liability of taxpayers regarding payment of fees according to the legislation and the amount of taxes actually paid voluntarily and on time. The scientist identifies three components of the tax gap: unregistered activities, understatement of tax payments and non-payment of taxes and duties [Toder]. Australian scientists J. McManus and $\mathrm{H}$. Warren characterize the tax gap as the difference between the theoretical tax liability under the law and actually collected revenues. "Sources of tax gaps, - the scientists underline - are diverse and complex, they may include: shadow economy, illegal activities, bad tax debts, unintentional errors. Dissatisfaction with the government and its spending, the complexity of tax laws, apathy and corruption are the reasons for non-payers of default on obligations and lead to tax gaps" [McManus, Warren, 2006].

British Her Majesty's Revenue and Customs (HMRC) proposes the following definition: "The tax gap is measured by the amount of taxes that were not ultimately collected or with the sum total of uncorrected violations oflaw" [Measuring Tax Gaps, 2010]. US Internal Revenue Service understands tax gaps as the sum total of taxes and duties established under the law, but not paid on time and in full [Internal Revenue Service, 2004]. The independent international association "Tax Justice Network" (TJN) focuses on the characteristics of tax gaps as a complex phenomenon, which greatly affects the stability of the state's income, standards of living, social justice, corporate responsibility [Mind the Tax Gap. The Tax Justice Network. January, 2006].

Thus, most scientists interpret the tax gaps as the amount of taxes that were not received with the budget as a result of shadow economy, tax evasion and tax debts.
However, considerable asymmetry of the tax component of the state budgetary resources also arises due to budget losses of all levels as a result of providing tax exemptions. In modern economic literature such losses are considered as tax expenditures.

Thus, the authors of the study "Tax expenditures in OECD countries" note that tax expenditures are the provisions of tax laws, regulations or practices that make it possible to reduce or defer paying taxes for a certain part of the population or taxpayers, due to deviation from the benchmark of tax structure [Tax expenditures in OECD countries, 2011]. Therefore, tax expenditures for a state mean decreasing its budgetary resources and for taxpayers they mean a reduction in tax liability. In this research the amount of tax expenditures is calculated with the method of lost income as the amount of taxes that would have been paid in the absence of tax exemptions.

N. Leheida includes in tax expenditures all kinds of fiscal policies that lead to the loss of budget revenue, including tax exemptions, free economic zones, tax credits, taxes payable, deferred taxes for various types of economic activity [Leheida, 2001]. M. Filo has a similar vision interpreting tax expenditures as losses of state due to providing tax exemptions, writing-off and reducing tax liabilities, deferring tax payments [Filo, 2012]. I. Maiburov considers tax expenditures as lost tax revenues of budget system connected with the use of various deviations from the normative tax structure by the legislature, which thus provide any benefits to certain types of activities or groups of taxpayers [Malynyna, 2010]. According to T. Malynyna, tax expenditures arise from the established tax exemptions and exemptions regarding the fundamental (regulatory) tax structure [Malynyna, 2010]. D. Serebryansky summarizes: "Generally speaking, tax expenditures are actually tax exemptions» [Maiburov, Ivanov, Taranhul, 2013].

We consider tax losses a generalizing concept including potential amounts of tax revenues that the state and local budgets have not received as a result of the existence of the phenomenon of "tax gaps" and "tax expenditures", and the amount of losses of the state budgetary resources in terms of their tax component is equal to the sum total of tax exemptions provided, unsettled tax debt and the loss of tax revenue due to the operation of shadow economy.

We call your attention to the fact that not only definitions are important. In fact, the point is not in abstract concepts, but in the phenomena and processes that are directly and immediately related to the optimization of the formation of state budget resources in conditions of deepening imbalances in public finance and increasing debt risks. Effective management of tax gaps and tax expenditures and, consequently, a decrease in tax losses of budgetary resources will ensure the correction of fiscal asymmetries and imbalances, will contribute to achieving fiscal equilibrium, will cause a synchronization of fiscal and monetary policy, and as a result, will reduce the need of Ukraine in loan financing and its debt bondage. 


\section{Tax gaps caused with shadow economy}

The most essential losses of state budgetary resources are caused with shadow economy. Undisclosed operations are inherent in almost all countries of the world, in fact according to the World Economic Forum (WEF) it is found that the major global risks over the next decade are spreading of undisclosed operations along with macroeconomic imbalances against the background of limited resources.

In Ukraine the main types of undisclosed activities are: conducting cash transactions without accounting; concealment of income or overstatement of expenditures; illegal payment of wages; underpricing company shares (in the process of sale of a majority stake in the company); illegal gratifications, "kickbacks"; money laundering; clandestine manufacture; illegal economic activities; fraud; "black markets" (illegal markets). The basis of the domestic shadow sector are operations in legal types of businesses that are conducted without full payment of all taxes or out of governmental control, for example, "grey" imports and envelopes wages. Income and earnings are hidden from the state not only by legal entities but also by individuals - for example, by farmers who sell their products in markets without reporting to the tax authorities.

According to generalizing calculations of the Ministry of Economic Development and Trade of Ukraine, shadow economy in Ukraine during last 11 years is in the range of $28.8 \%$ to $41.0 \%$ of GDP (Fig. 1).

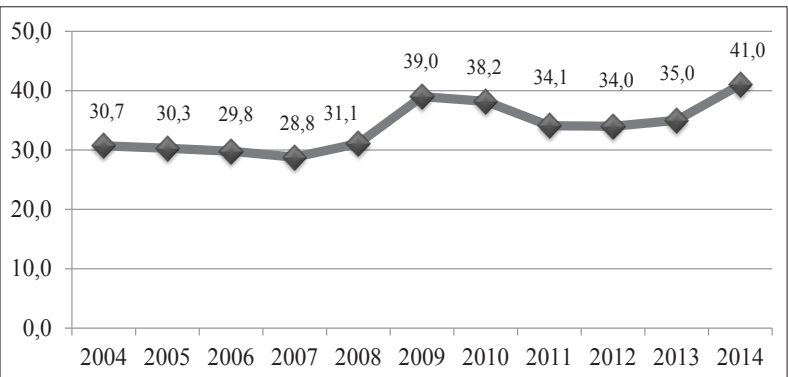

Fig. 1. Integrated index of shadow economy in Ukraine, \% of official GDP

Note: developed by the author of this article based on the data given in [12]
As shown in Fig. 1, the official amount of shadow economy in Ukraine (\% of GDP), is almost twice as the corresponding average in Europe. Obviously, such a powerful shadow sector adjusts the performance of national fiscal policy towards its deterioration.

Using the integrated index of shadow economy, calculated by the Ministry of Economic Development and Trade of Ukraine and the level of tax index we are able to determine the amount of "shadow" tax gaps in Ukraine (Table 1).

As shown in Table 1, from 2004 to 2014 losses of budgets of all levels in Ukraine due to the shadow sector functioning increased 7.8 (!) times and reached the value of 150.7 billion UAH in 2014. By comparison, the same year Ukraine's budget expenditures on social protection and social security amounted to 138.0 billion UAH, on education -100.1 billion UAH, on healthcare -57.2 billion UAH, on defense - 27,4 billion UAH.

Note, however, that a complete return of the funds lost due to the existence of shadow sector to budget is impossible. Thus, according to the foreign researchers, introducing measures "closing" the tax gaps of a certain size does not necessarily lead to an increase in tax revenue by the same amount - "only about $1 / 3$ of the shadow economy activity level will continue to exist in formal economy", thus, "it is assumed that only $1 / 3$ of the tax gap in each Member State can be converted into actual tax revenue" [Muller, 2013].

\section{Tax debt}

Another important component of tax losses of the state budget resources are losses caused by inefficient management of tax debt, which is the result of taxpayers' neglecting their constitutional duty to pay taxes. In accordance with paragraph 175 sub-paragraph 1, Article 14 of the Tax Code of Ukraine tax debt is a sum of agreed money obligation (including penalties, if any) not paid by a taxpayer in terms established by the Tax Code of Ukraine as well as penalty charged on the sum of the money obligation [The Tax Code of Ukraine].

Table 1

Tax gaps caused by shadow economy in Ukraine

\begin{tabular}{|l|c|c|c|c|c|c|c|c|c|c|c|}
\hline \multicolumn{1}{|c|}{ Indicators } & 2004 & 2005 & 2006 & 2007 & 2008 & 2009 & 2010 & 2011 & 2012 & 2013 & 2014 \\
\hline GDP, billion. UAH. & 345,1 & 441,5 & 544,2 & 720,7 & 948,1 & 913,3 & 1082,6 & 1316,6 & 1408,9 & 1454,9 & 1566,7 \\
\hline $\begin{array}{l}\text { Level of shadow } \\
\text { economy, \% }\end{array}$ & 30,7 & 30,3 & 29,8 & 28,8 & 31,1 & 39,0 & 38,2 & 34,1 & 34,0 & 35,0 & 41,0 \\
\hline $\begin{array}{l}\text { Shadow economy size, } \\
\text { billion. UAH. }\end{array}$ & 105,9 & 133,8 & 162,2 & 207,6 & 294,9 & 356,2 & 413,6 & 449,0 & 479,0 & 509,2 & 642,3 \\
\hline $\begin{array}{l}\text { Tax revenues of the } \\
\text { Consolidated Budget } \\
\text { of Ukraine, billion. UAH. }\end{array}$ & 63,2 & 98,1 & 125,7 & 161,3 & 227,2 & 208,1 & 234,4 & 334,7 & 360,6 & 354 & 367,5 \\
\hline Budget tax index,\% & 18,31 & 22,22 & 23,10 & 22,38 & 23,96 & 22,79 & 21,65 & 25,42 & 25,59 & 24,33 & 23,46 \\
\hline $\begin{array}{l}\text { The amount of tax } \\
\text { gaps caused by shadow } \\
\text { economy, billion. UAH. }\end{array}$ & 19,4 & 29,7 & 37,5 & 46,5 & 70,7 & 81,2 & 89,5 & 114,1 & 122,6 & 123,9 & 150,7 \\
\hline
\end{tabular}

Note: developed by the author of this article based on the data given in $[12 ; 13 ; 14]$ 
O. Desiatniuk and T. Marshal stress that tax debt arises as a result of errors committed in socio-economic policy of the state and attend to the inconsistent relations of regulatory authorities with legal entities and individuals in the formation of the tax component of the state budget revenue [Desiatniuk, 2013].

The accumulation of significant amounts of tax debt of economic agents is a significant factor in reducing fiscal efficiency of tax sources of budgetary resources of the state. Let us consider the dynamics of tax debt in Ukraine during the period of 2004-2014 (Fig. 2).

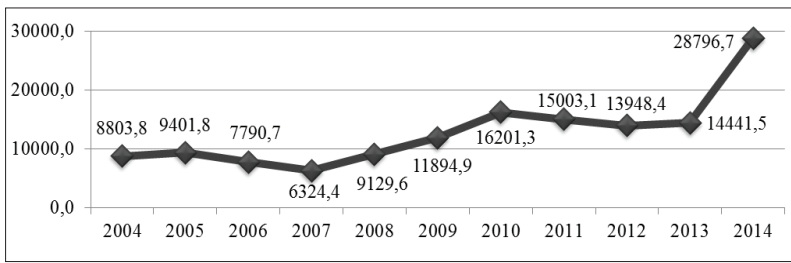

Fig. 2. Dynamics of tax debt in Ukraine, bln. UAH

Note: developed by the author of this article based on the data given in [18]

Therefore, we observe the rapid growth of tax debt (excluding bankrupts) during the global financial crisis (from 9.1 bln. UAH. In 2008 to 16.2 bln. UAH. In 2010, i.e. 1.8 times ). Over the period 2011-2014 the amount of tax debt declined slightly. Extremely complicated economic situation in 2014 caused double tax debt growth compared with the year earlier and it grew 3.3 times compared with the value of 2004, the economic agents' debt reached a critical peak - 28,8 bln. UAH.

One of the substantial reasons that cause the untimely fulfillment of tax liabilities is taxpayers' waiting (large ones in particular) for writing-off or restructuring of the tax debt. This not only affects negatively the quality of the formation of the state budget resources but also has an unfavorable impact on the basic principles that constitute a guarantee of taxation effectiveness. The principles of fairness and uniformity are violated, and as a result, law-abiding taxpayers come off losers. In addition, endorsing views of $\mathrm{V}$. Melnyk we state that restructuring tax debts, in fact, is lending through the budget [Melnyk, 2006]. Naturally, its beneficiaries have a direct interest in continuing this practice. As a result, these factors produce further accumulation of tax debt of business entities.

However, the management of tax debt by supervisory authorities remains ineffective, and tax management techniques in the field of repayment are still imperfect. This in turn leads to an increase in tax debt, the emergence of significant losses of budgetary resources and, as a result, tends to reduce potential influence of the state on ensuring the continuity of expanded reproduction and meeting other social needs.

\section{Tax exemptions}

Another significant factor in producing tax losses of budgetary resources of the state are tax exemptions and privileges that are a priori intended to stimulate the development of certain activities, industries and individual businesses and regions; state regulation of prices; ensuring the competitiveness of strategically important goods in terms of state in comparison with cheap imports. "Using certain tax exemptions, the state regulates economic proportions in the economic framework of production and exchange, the proportions in the development of the productive forces," emphasizes A. Krysovatyi [Krysovatyi, 2005].

World theory and practice of preferential taxation shows that tax exemptions have a two-stage set of consequences: first a tax incentive reduces the amount of tax revenue, that is, reduces the fiscal effectiveness of taxes, but then, provided a balanced approach to its provision, tax revenues may, if not increase, at least return to the previous level due to the favorable impact of tax exemptions and preferences on the financial and economic situation of the payer.

However, the situation in Ukraine is not as ambiguous: exemptions are provided to taxpayers in large amounts, but they do not always give the expected result. Major part of the tax preferences is aimed at meeting the needs of particular businesses or representatives of government and is subject to lobbying interests. The absence of an effective system of

Table 2

Tax losses of budgetary resources of Ukraine caused by tax exemptions

\begin{tabular}{|c|c|c|c|c|c|}
\hline \multirow{2}{*}{ Year } & \multirow{2}{*}{ Total, thousand UAH } & \multicolumn{2}{|c|}{ State budget losses } & \multicolumn{2}{c|}{ Local budget losses } \\
\cline { 3 - 5 } & & thousand UAH & ratio, $\%$ & thousand UAH & ratio, \% \\
\hline 2004 & 12550461 & 12311551 & 98,10 & 238910 & 1,90 \\
\hline 2005 & 12338011 & 12076553 & 97,88 & 261457 & 2,12 \\
\hline 2006 & 13502686 & 13275093 & 98,31 & 227593 & 1,69 \\
\hline 2007 & 17472201 & 17021536 & 97,42 & 450665 & 2,58 \\
\hline 2008 & 22845418 & 22262299 & 97,45 & 583120 & 2,55 \\
\hline 2009 & 28207620 & 27507998 & 97,52 & 699622 & 2,48 \\
\hline 2010 & 37127375 & 36133031 & 97,32 & 994343 & 2,68 \\
\hline 2011 & 59166617 & 58832522 & 99,44 & 334095 & 0,56 \\
\hline 2012 & 48659120 & 48108083 & 98,87 & 551037 & 1,13 \\
\hline 2013 & 35630853 & 34765047 & 97,57 & 865806 & 2,43 \\
\hline 2014 & 33213316 & 32521465 & 97,92 & 691851 & 2,08 \\
\hline
\end{tabular}

Note: calculated by the author of this article based on the data given in [18] 
controlling the use of tax exemptions, their ungrounded extension, on the one hand, leads to significant losses of state budget resources; on the other hand it unfairly shifts the tax burden on efficient enterprises that do not benefit from tax preferences. Thus, due to the inversion of social logic providing tax exemptions in Ukraine produces a significant increase in tax losses of the state budget resources, violates the principle of neutrality and has a destructive impact on the macroeconomic and fiscal stability.

"The existing system of tax exemptions - states Ts. Ogon - leads to permanent loss of budget revenue and slows down business development in Ukraine" [Ohon, 2003]. Analysis of the data provided by the State Fiscal Service of Ukraine allows distinguishing between tax losses of state and local budgets due to the current system of preferential taxation (Table 2).

During 2004-2014 a steady growth trend in tax losses of state budget resources is observed caused with providing tax exemptions, during this period they increased more than 2.5 times (maximum value - $59.2 \mathrm{bln}$. UAH was observed in 2011). The dominant budgetary losses caused with preferential tax are the state budget losses.

We emphasize that this calculation does not include tax exemptions provided by the customs authorities, in 2008 - 11.7 bln. UAH, in $2009-12.4$ bln. UAH, in 2010 - 22.1 bln. UAH, in $2011-44.0$ bln. UAH, in $2012-$ 42.9 bln. UAH, in 2013 - 44.1 billion. UAH, in 2014 $32.2 \mathrm{bln}$. UAH. Moreover, the tax authorities keep records of tax exemptions only according to the following taxes: corporate income tax, land tax, VAT, excise tax, fee for parking vehicles, tourist tax, public due. So, presented amounts of tax losses of the Consolidated budget of Ukraine caused by tax exemptions are not exhaustive and do not fully reflect the real situation.

\section{Tax losses of budgetary resources of Ukraine}

Let us generalize calculated values of tax losses of state budget resources caused by the existence of the phenomena of "tax gaps" and "tax expenditures" in Table 3.

The table shows enormous losses of budgetary resources in Ukraine due to the imperfection of the tax system, spread of undisclosed operations, tax evasion, and inefficient fiscal policy implementation. The Consolidated budget loses the amounts of monetary funds, equal to an average of $53.30 \%$ of actual revenue over the period studied. Total tax losses of the state budgetary resources in 2014 are equivalent to the total actual expenditures of the Consolidated budget of Ukraine on social protection and social security, defense, public order, security and judicial authorities.

\section{Conclusions}

With regard to the prospects for the mobilization to the budget of taxes and duties lost due to the functioning of the shadow sector in the state, we note that even taking into account the point of view of foreign economists that only $1 / 3$ of the tax gap can be converted into actual tax revenues in case of implementing measures of legalization of the economy, additional budgetary resources of the Consolidated budget of Ukraine obtained due to the elimination of tax gaps would be significant.

We emphasize that noless important factor in overcoming the imbalances of public finances and stabilizing the domestic fiscal space is directing additional tax revenues use grounded on social intuition and economic expediency. Mobilized resources can be directed to:

- Reducing the budget deficit - in this case, taxpayers who operate in the legalized economy do not receive any benefits from the elimination of the tax gap;

Table 3

Tax losses of budgetary resources of Ukraine, bln. UAH.

\begin{tabular}{|c|c|c|c|c|c|c|c|c|c|c|c|}
\hline Indicators & 2004 & 2005 & 2006 & 2007 & 2008 & 2009 & 2010 & 2011 & 2012 & 2013 & 2014 \\
\hline GDP & 345,1 & 441,5 & 544,2 & 720,7 & 948,1 & 913,3 & 1082,6 & 1316,6 & 1408,9 & 1454,9 & 1566,7 \\
\hline $\begin{array}{l}\text { Revenues of the } \\
\text { Consolidated budget of } \\
\text { Ukraine }\end{array}$ & 91,5 & 134,2 & 171,8 & 219,9 & 297,9 & 273,0 & 314,5 & 398,6 & 445,5 & 442,8 & 456,1 \\
\hline $\begin{array}{l}\text { Tax revenues of the } \\
\text { Consolidated budget of } \\
\text { Ukraine }\end{array}$ & 63,2 & 98,1 & 125,7 & 161,3 & 227,2 & 208,1 & 234,4 & 334,7 & 360,6 & 354 & 367,5 \\
\hline \multicolumn{12}{|l|}{ Tax expenditures and gaps: } \\
\hline Tax exemptions & 12,6 & 12,3 & 13,5 & 17,5 & 22,8 & 28,2 & 37,1 & 59,2 & 48,7 & 35,6 & 33,2 \\
\hline Unsettled tax debt & 8,8 & 9,4 & 7,8 & 6,3 & 9,1 & 11,9 & 16,2 & 15,0 & 13,9 & 14,4 & 28,8 \\
\hline $\begin{array}{l}\text { Tax losses caused by } \\
\text { shadow economy }\end{array}$ & 19,4 & 29,7 & 37,5 & 46,5 & 70,7 & 81,2 & 89,5 & 114,1 & 122,6 & 123,9 & 150,7 \\
\hline \multicolumn{12}{|c|}{ Tax expenditures and gaps, total: } \\
\hline - bln. UAH & 40,8 & 51,4 & 58,8 & 70,3 & 102,6 & 121,3 & 142,8 & 188,3 & 185,2 & 173,9 & 212,7 \\
\hline - \% of GDP & 11,82 & 11,64 & 10,80 & 9,75 & 10,82 & 13,28 & 13,19 & 14,30 & 13,15 & 11,95 & 13,58 \\
\hline $\begin{array}{l}\text { - \% of revenues of the } \\
\text { Consolidated budget }\end{array}$ & 44,59 & 38,30 & 34,23 & 31,97 & 34,44 & 44,43 & 45,41 & 47,24 & 41,57 & 39,27 & 46,63 \\
\hline $\begin{array}{l}\text { - } \% \text { of tax revenues of the } \\
\text { Consolidated budget }\end{array}$ & 64,56 & 52,40 & 46,78 & 43,58 & 45,16 & 58,29 & 60,92 & 56,26 & 51,36 & 49,12 & 57,88 \\
\hline
\end{tabular}

Note: calculated by the author of this article based on the data given in $[13 ; 14 ; 18]$ 
- Reducing the tax burden of taxpayers who conduct business activity in the legalized economy;

- An increase in expenditures in an equivalent amount;

- A combination of reducing the tax burden on taxpayers who work in the legalized economy, increasing budget expenditures and reducing the budget deficit, which is the best option, aimed at reaching a constructive compromise of the interests of the state and economic agents as the main producers of tax revenues to the Consolidated budget of Ukraine.
Thus, the major reserves to increase the tax component of budgetary resources of the state with preventing tax losses lie exactly in the plane of fiscal policy optimization and legalization of assets of business entities. Changing priorities of fiscal mechanisms existing in Ukraine towards establishing parity relations between tax authorities and taxpayers will create a favorable climate for their joint activities which is an objective social basis for ensuring completeness and stability of tax sources of budgetary resources as the financial background in achieving a common goal: building economically developed democratic state.

\section{References}

Monitoring Taxpayers' Compliance: A Practical Guide Based on Revenue Body Experience (2008). Final Report. Forum on Tax Administration: Compliance Sub. - Group, 82 p.

Toder, E. J. What Is the Tax Gap? [Electronic resource]. - Retrieved from: http://www.urban.org/ UploadedPDF/1001112_tax_gap.pdf

McManus, J., Warren, N. (2006). The Case for Measuring Tax Gap. Journal of Tax Research, 4 (1) [Electronic resource]. - Retrieved from: http://www.austlii.edu.au/au/journals/eJTR/2006/3.html

Measuring Tax Gaps (2010). An Official Statistics Release16th September 2010 [Electronic resource]. - Retrieved from: http://www.hmrc.gov.uk/stats/measuring-tax-gaps.pdf

Internal Revenue Service (2004). «Overview of the Federal Tax Gap» IRS NHQOffice of Research. September 20, 2004 [Electronic resource]. - Retrieved from: http://www.taxadmin.org/fta/meet/re_pres04/Plumley.pdf

Mind the Tax Gap. The Tax Justice Network. January (2006). [Electronic resource]. - Retrieved from: http://www.taxjustice.net/cms/upload/pdf/Mind_the_Tax_Gap___final_-_15_Jan_2006.pdf

Tax expenditures in OECD countries (2011). [Electronic resource]. - Retrieved from: http:// www.planejamento.gov.br/secretarias/upload/Arquivos/seges/arquivos/OCDE2011/OECD_Tax.pdf

Leheida, N. (2001). Indirect subsidies in Ukraine: evaluation, trends and consequences for economic policy. Scientific materials № 10 Institute of Economic Research and Political Consulting. - Kyiv, October, 40 p. [Electronic resource]. - Retrieved from: http://www.ier.com.ua/files/publications/WP/2001/Wp10_ukr.pdf

Filo, M. (2012). The problem of budget losses caused by tax exemptions and the ways of its solving. Economic Journal - XXI, issue 3-4, p. 73-76.

Maiburov, I.A., Ivanov, Y.B., Taranhul L.L (2013). The economy of tax reforms: Monograph. - K.: Alerta, 432 p.

Malynyna, T. (2010). Evaluation of tax incentives and exemptions: foreign experience and the Russian practice. M.: IEPP, 212 p.

Official website of the Ministry of Economic Development and Trade of Ukraine [Electronic resource]. - Retrieved from: http://www.me.gov.ua

The official website of the State Treasury Service of Ukraine [Electronic resource]. - Retrieved from: http://www.treasury.gov.ua

The official website of the State Statistics Service of Ukraine [Electronic resource]. - Retrieved from: http://www.ukrstat.gov.ua.

Muller, P. (2013). From Shadow to Formal Economy: Levelling the Playing Field in the Single Market. Policy Department of European Parliament, 108 p.

The Tax Code of Ukraine of 02.12.2010 № 2755-VI [Electronic resource]. - Retrieved from: http://zakon4.rada.gov.ua/laws/show/2755-17

Desiatniuk, O.M. (2013). Tax debt management : Tutorial. - Ternopil: Vector, 340 p.

The official website of the State Fiscal Service of Ukraine [Electronic resource]. - Retrieved from: http://sfs.gov.ua/

Melnyk, V.M. (2006). Tax debt in Ukraine: causes and methods of reducing. Scientific Journal of the National Academy of State Fiscal Service of Ukraine (economics, law): NASFSU, issue 3 (34), p. 74-81.

Krysovatyi, A.I. (2005). Theoretical and organizational dominants and practice of the implementation of fiscal policy in Ukraine: Monograph. - Ternopil: Carte-blanche, 2005. - 371 p.

Ohon, Ts.H. (2003). Budget revenues in Ukraine: Theory and Practice. Monograph. - K.: Kyiv National Economical and Trade University, $580 \mathrm{p}$. 


\section{Лариса СИДЕЛЬНИкОВА}

\section{ФЕНОМЕН НАЛОГОВЫХ ПОТЕРЬ БЮДЖЕТНЫХ РЕСУРСОВ ГОСУДАРСТВА}

Аннотация. Целью работы является структуризация категориально-понятийного аппарата феномена налоговых потерь бюджетных ресурсов государства, а именно: уточнение понятий «налоговый разрыв», «налоговые расходы», «налоговые потери», а также определение объемов налоговых потерь Сводного бюджета Украины. Методика. Большинство современных исследователей трактуют налоговые разрывы как сумму налогов, которые не поступили в бюджет в результате теневой экономики, уклонения от уплаты налогов и наличия налогового долга. В то же время, значительные асимметрии налоговой компоненты бюджетных ресурсов государства возникают и в результате потерь бюджетов всех уровней от предоставления налоговых льгот. В современной экономической литературе такие потери принято трактовать как налоговые расходы. Считаем, что понятие «налоговые потери» обобщает и включает в себя потенциально возможные объемы налоговых поступлений, которые государственный и местные бюджеты не получили в результате существования феноменов «налоговые разрывы» и «налоговые расходы», а объем потерь бюджетных ресурсов государства в части их налоговой составляющей равняется сумме предоставленных налоговых льгот, непогашенного налогового долга субъектов хозяйствования и потерь налоговых поступлений в результате функционирования теневой экономики. Исследование основывается на анализе налоговых потерь бюджетных ресурсов Украины в период 2004-2014 годов. Результаты исследования засвидетельствовали колоссальные потери бюджетных ресурсов в Украине в результате несовершенства налоговой системы, распространения теневых операций, уклонения от налогообложения, неэффективной реализации налоговой политики. Сводный бюджет теряет объемы денежных средств, равных в среднем 53,30\% фактических налоговых поступлений на протяжении исследуемого периода. Сумма налоговых потерь бюджетных ресурсов государства в 2014 году эквивалентна суммарным фактическим расходам Сводного бюджета Украины на социальную защиту и социальное обеспечение, оборону, общественный порядок, безопасность и судебную власть. Даже с учетом позиции зарубежных экономистов, что лишь 1/3 налогового разрыва при внедрении мероприятий по детенизации экономики может быть переведена в фактические налоговые поступления, дополнительные ресурсы Сводного бюджета Украины от ликвидации налоговых разрывов будут весомыми. Определено, что эффективное управление налоговыми разрывами и налоговыми расходами, а, следовательно, снижение объемов налоговых потерь бюджетных ресурсов обеспечит коррекцию фискальных асимметрий и дисбалансов, будет способствовать достижению фискального равновесия государства, обусловит синхронизацию фискальной и монетарной политики, и в итоге, позволит сократить потребности Украины в долговом финансировании и снизить ее долговую зависимость. Практическое значение. Обоснование выводов, что основные резервы увеличения налоговой компоненты бюджетных ресурсов государства путем предотвращения налоговых потерь кроются именно в плоскости оптимизации налоговой политики и выведения активов субъектов хозяйствования из «тени», позволяет разработать направления совершенствования налоговых форм финансирования общественных расходов. Значение/оригинальность. Полученные данные способны обеспечить лучшее понимание причин дисбалансов государственных финансов Украины и путей их стабилизации. 